\title{
Effects of lime and coco peat on the uptake of Cadmium in peanut grown on alluvial soil without compensation in An Phu - An Giang
}

\author{
Loc T. V. Do* , \& Chuong V. Nguyen
}

Faculty of Agriculture and Natural Resources, An Giang University, An Giang, Vietnam

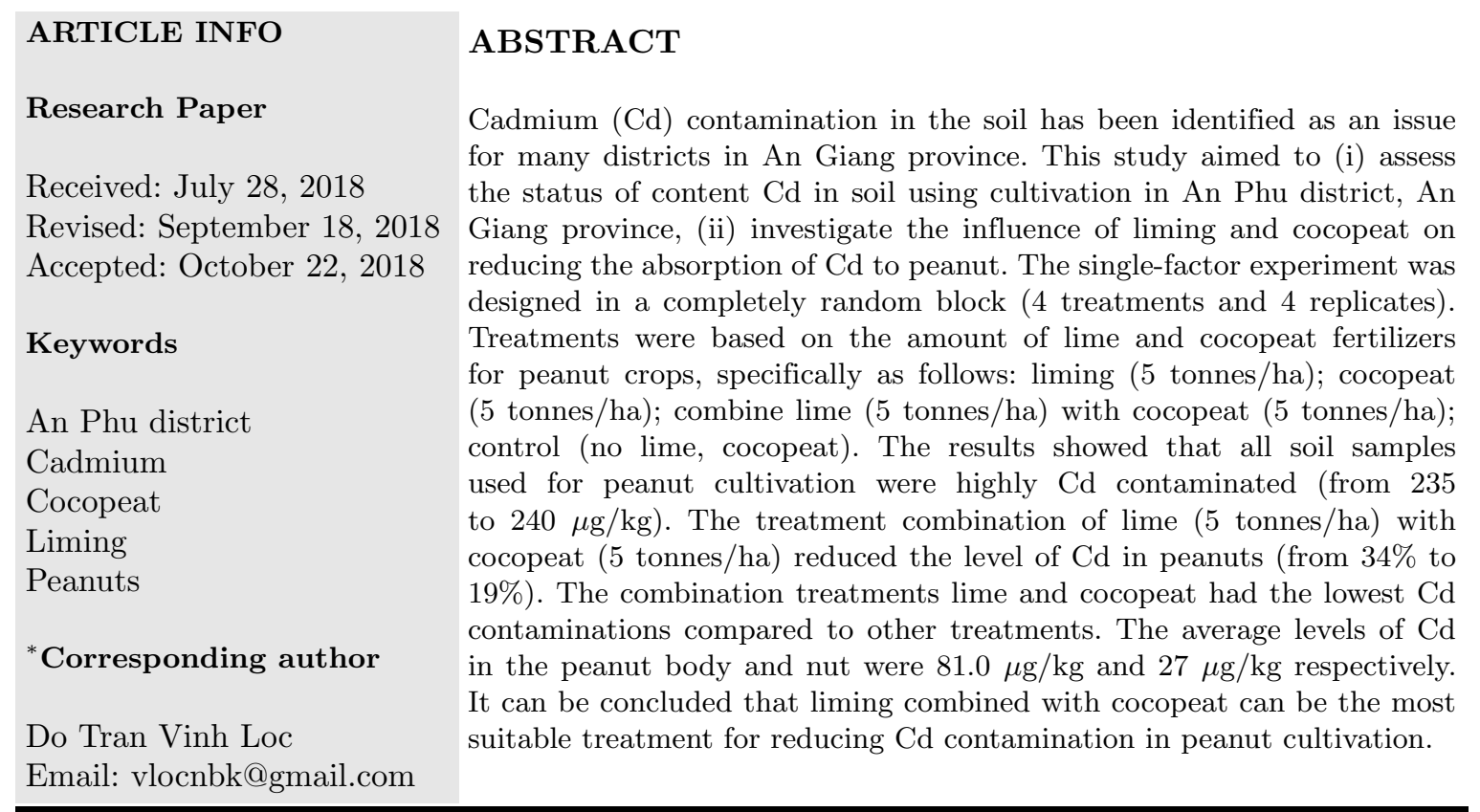

Cited as: Do, L. T. V., \& Nguyen, C. V. (2019). Effects of lime and coco peat on the uptake of Cadmium in peanut grown on alluvial soil without compensation in An Phu - An Giang. The Journal of Agriculture and Development 18(2), 49-56. 


\title{
Ảnh hưởng của vôi và mụn dừa đến sự hấp thu Cadimi trong cây đậu phộng (Arachis hypogaea L.) trồng trên đất phù sa không bồi tại An Phú - An Giang
}

\author{
Đỗ Trần Vĩnh Lộc* \& Nguyễn Văn Chương
}

Khoa Nông Nghiệp và Tài Nguyên Thiên Nhiên, Trường Đại Học An Giang, An Giang

\author{
THÔNG TIN BÀI BÁO \\ Bài báo khoa học \\ Ngày nhận: 28/07/2018 \\ Ngày chỉnh sửa: 18/09/2018 \\ Ngày chấp nhận: 22/10/2018
}

\section{Từ khóa}

An Phú

Cadimi

Đậu phộng

Mụn dừa

Vôi

\section{*Tác giả liên hệ}

Đỗ Trần Vĩnh Lộc

Email: vlocnbk@gmail.com

\section{TÓM TẮT}

Ngày nay, ô nhiễm Cadimi $(\mathrm{Cd})$ trong đất đã được cảnh báo rất nhiều huyện trong tỉnh An Giang. Nghiên cứu Ảnh hưởng của vôi và mụn dừa đến sự hấp thu Cadimi trong cây đậu phộng (Arachis hypogaea L.) trồng trên đất phù sa không bồi tại An Phú-An Giang đã được thực hiện với các mục tiêu: (i) đánh giá thực trạng hàm lượng $\mathrm{Cd}$ trong môi trường đất sử dụng trồng trọt tại huyện An Phú, tỉnh An Giang, (ii) ảnh hưởng của bón vôi và mụn dừa đến sự giảm hút thu $\mathrm{Cd}$ lên cây đậu phộng. Thí nghiệm đơn yếu tố được bố trí theo kiểu khối đầy đủ hoàn toàn ngẫu nhiên, 4 nghiệm thức và 4 lần lặp lại. Các nghiệm thức được xây dựng dựa vào lượng vôi và mụn dừa bón cho cây đậu phộng, cụ thể như sau: bón vôi $(5$ tấn/ha); bón mụn dừa (5 tấn/ha); bón kết hợp vôi (5 tấn/ha) với mụn dừa (5 tấn/ha); Đối chứng (không bón vôi, mụn dừa). Thí nghiệm được thực hiện ngoài đồng ruộng nằm trong đê bao. Kết quả nghiên cứu cho thấy tất cả các mẫu đất nơi thí nghiệm trồng đậu phộng đều nhiễm $\mathrm{Cd}$ cao từ $235 \mu \mathrm{g} / \mathrm{kg}$ đến $240 \mu \mathrm{g} / \mathrm{kg}$. Nghiệm thức bón kết hợp vôi ( 5 tấn/ha) với mụn dừa $(5$ tấn/ha) có hàm lượng $\mathrm{Cd}$ trong hạt và trong thân của đậu phộng thấp hơn nghiệm thức không có bón vôi và mụn dừa lần lượt là $34 \%$ và $19 \%$. Hàm lượng $\mathrm{Cd}$ trung bình trong thân là $81,0 \mu \mathrm{g} / \mathrm{kg}$, hạt là $27 \mu \mathrm{g} / \mathrm{kg}$ ở nghiệm thức bón vôi kết hợp mụn dừa thấp nhất so với các nghiệm thức còn lại. Từ đó có thể kết luận việc bón vôi kết hợp với mụn dừa cho thấy hiệu quả giảm sự hấp thu Cd lên cây đậu phộng tốt nhất và thấp nhất là trồng không bón vôi và mụn dừa.

\section{1. Đặt Vấn Đề}

Theo kết quả một số nghiên cứu ở An Giang (Nguyen, 2003) chỉ ra rằng nồng độ Cadimi $(\mathrm{Cd})$ trong đất cao $(0,56 \mu \mathrm{g} / \mathrm{kg})$ hơn các vùng khác ở Đồng bằng sông Cửu Long (ĐBSCL). Theo kết quả một số nghiên cứu ở An Giang (Nguyen \& Ngo, 2015) chỉ ra rằng nồng độ $\mathrm{Cd}$ trong đất cao $(0,362 \mu \mathrm{g} / \mathrm{kg})$ hơn các vùng khác ở ĐBSCL. Phân tích mẫu bắp, lúa và đậu xanh từ ruộng nông dân ở An Phú (Nguyen \& Ngo, 2012) cho thấy hàm lượng $\mathrm{Cd}$ trong hạt vượt ngưỡng $100 \mu \mathrm{g} / \mathrm{kg}$ đối với bắp, lúa và đậu xanh được xếp theo thứ tự là $6,67 \%$; $20,0 \%$ và $93,3 \%$ dựa theo tiêu chuẩn quốc tế về hàm lượng $\mathrm{Cd}$ trong nông sản. Điều này cho thấy nguy cơ gây nhiễm Cd lên các chuỗi thức ăn (Mclaughlin \& ctv., 1998). Cd không những tích lũy ở thận, mà cả trong xương, gây ung thư và các bệnh về xương ở người (Nogawa, 1984). Nghiên cứu của Chen \& ctv. (2000) cho rằng sự hấp thu Cd bởi cây trồng giảm đáng kể bằng cách tăng $\mathrm{pH}$ của đất do bón vôi thì Cd bị kết tủa ở dạng $\mathrm{CdCO}_{3}$. Nghiên cứu của Shukla \& ctv. (2006) cho rằng mụn dừa chứa 45,84\% hàm lượng lignin, loại này có mạng lưới cấu trúc là methoxy và các nhóm hydroxyt tự do, cả hai hợp chất này đều có khả năng hấp phụ các ion kim loại nặng và giữ chúng trên bề mặt vật liệu.

Với những nghiên cứu trên đã dẫn đến vấn đề là đất và cây trồng có thể bị nhiễm $\mathrm{Cd}$ và sức khỏe con người sẽ bị ảnh hưởng khi tiêu thụ các nông sản ở đây. Trước thực trạng đó, nghiên cứu ứng dụng vôi, mụn dừa nhằm giảm hấp thu $\mathrm{Cd}$ trên cây đậu phộng trồng trên đất phù sa không 
bồi tại An Phú - An Giang được thực hiện.

\section{Vật Liệu và Phương Pháp Nghiên Cứu}

\subsection{Vật liệu}

Đất thí nghiệm là nền đất trong đê tưới nước giếng khoan tại xã Quốc Thái, huyện An Phú, tỉnh An Giang. Thời gian trồng vụ Đông Xuân năm 2017.

Giống đậu L14 được sử dụng trong nghiên cứu là giống được công nhận chính thức là giống tiến bộ kỹ thuật theo Quyết định số 5310/BNNKHKT ngày 29 tháng 11 năm 2002.

Giống đậu L14 có đặc điểm thân đứng, tán gọn, kháng bệnh lá, bệnh héo xanh khá; có quả to, eo nông, gân quả nông, vỏ lụa màu hồng. Thời gian sinh trưởng của L14: vụ xuân 120 125 ngày; vụ thu và thu đông là 100 - 110 ngày. Thân đứng, tán gọn, kháng bệnh lá, bệnh héo xanh khá; chịu thâm canh với năng suất trung bình $4-4,5$ tấn/ha.

Vôi $(\mathrm{CaO})$ liều lượng 5 tấn/ha, mụn dừa $(5$ tấn/ha) phải được ngâm nước, phơi khô để loại tannin trước khi sử dụng.

Thang đánh giá tham khảo hàm lượng $\mathrm{Cd}$ trong đất và nông sản: Theo QCVN 03:2015/BTNMT của Bộ Tài nguyên và Môi trường về giới hạn hàm lượng $\mathrm{Cd}$ trong đất nông nghiệp là 1,5 mg/kg đất khô. Theo QCVN 8-2:2011/BYT của Bộ $\mathrm{Y}$ Tế về giới hạn hàm lượng $\mathrm{Cd}$ tối đa trong nông sản là $0,1 \mathrm{mg} / \mathrm{kg}$ chất khô $(\mathrm{MOH}, 2011)$.

\subsection{Phương pháp nghiên cứu}

Nghiên cứu trên cây đậu phộng được bố trí ngoài đồng ruộng trong đê bao khép kín. Thí nghiệm đơn yếu tố được bố trí theo kiểu khối hoàn toàn ngẫu nhiên, gồm 4 nghiệm thức. Các nghiệm thức được bố trí để giảm hấp thu $\mathrm{Cd}$ trên cây đậu phộng được trình bày ở Bảng 1 .

Bảng 1. Các nghiệm thức được bố trí để giảm hấp thu Cd trên cây đậu phộng

\begin{tabular}{lcc}
\hline Nghiệm thức & $\begin{array}{c}\text { Liều lượng } \\
\text { vôi } \\
\text { (tấn/ha) }\end{array}$ & $\begin{array}{c}\text { Liều lượng } \\
\text { mụn dừa } \\
\text { (tấn } / h a)\end{array}$ \\
\hline 1 (đối chứng) & 0 & 0 \\
2 (bón vôi) & 5 tấn $/$ ha & 0 \\
3 (bón mụn dừa) & 0 & 5 tấn $/$ ha \\
4 (vôi + mụn dừa) & 5 tấn $/$ ha & 5 tấn $/$ ha \\
\hline
\end{tabular}

Mỗi nghiệm thức đều có 4 lần lặp lại, với diện tích của mỗi lần lặp lại ở mỗi nghiệm thức tương đương $8 \mathrm{~m}^{2}(2 \mathrm{~m} \mathrm{x} 4 \mathrm{~m})$, mỗi lần lặp lại trồng 4 hàng với khoảng cách giữa các hàng $50 \mathrm{~cm}$; cây cách cây $20 \mathrm{~cm}$ (gieo 01 hạt/hốc), mỗi ô nghiệm thức cách nhau bởi mương rộng $50 \mathrm{~cm}$. Tổng diện tích thí nghiệm $10 \mathrm{~m}$ x $18 \mathrm{~m}=180 \mathrm{~m}^{2}$.

Mẫu đất được thu trước khi thí nghiệm và khi thu hoạch, mẫu đất sẽ được thu khoảng 1 $\mathrm{kg} / \mathrm{mẫu}$, ở độ sâu $0-20 \mathrm{~cm}$. Trong mỗi mẫu thu 05 điểm theo đường chéo góc, sau đó trộn chung lấy mẫu đại diện. Mẫu được phơi ở nhiệt độ phòng đến khi khô, sau đó được nghiền và qua rây có mắt lưới $0,5 \mathrm{~mm}$, kiểm tra $\mathrm{pH}$ (đất/nước tỉ lệ $1: 2,5)$ và phân tích $\mathrm{Cd}$; Mẫu hạt và thân đậu phộng được thu lúc thu hoạch và sấy khô sau đó tiến hành phân tích mẫu trên máy hấp thu nguyên tử bằng kỹ thuật hóa hơi lạnh (Hydride) để phân tích $\mathrm{Cd}$.

\subsection{Kỹ thuật canh tác}

Hạt giống được phơi khô trong điều kiện nắng nhẹ, loại bỏ những hạt sâu, hạt mốc, hạt đã nảy mầm, hạt tróc vỏ lụa hoặc hạt bị vỡ. Đất trồng được làm tơi xốp, sạch cỏ, Công thức phân bón vô cơ $40 \mathrm{~kg} \mathrm{~N}+60 \mathrm{~kg} \mathrm{P}_{2} \mathrm{O}_{5}+60 \mathrm{~kg} \mathrm{~K} \mathrm{~K}_{2} \mathrm{O} / \mathrm{ha}$, chia thành 03 dợt bón như sau:

- Bón lót: Toàn bộ lượng phân lân, 20\% đạm và $30 \%$ kali.

- Bón thúc 1 (15 NSG): Bón 40\% đạm và 30\% kali.

- Bón thúc 2 (25 - 30 NSG): Bón 40\% đạm và $40 \%$ kali.

- Loại vôi sử dụng là $\mathrm{CaO}$, liều lượng bón: 5 tấn/ha; thời gian bón: Chia làm 03 giai đoạn bón: Bón lót khi làm đất ( $50 \%$ lượng vôi); 30 ngày sau gieo (25\% lượng vôi) và $45-50$ ngày sau gieo $(25 \%$ lượng vôi), bón riêng rẽ không nên trộn với bất kỳ loại phân nào khác. Mụn dừa phải được ngâm nước, phơi khô để loại tannin trước khi sử dụng; Liều lượng bón: 5 tấn/ha. Thời gian bón: Chia làm 03 giai đoạn bón: Bón trên mặt líp sau khi gieo hạt (50\% lượng mụn dừa); 25 ngày sau gieo (25\% lượng mụn dừa) và 45 ngày sau gieo (toàn bộ lượng còn lại).

Hạt giống được gieo bằng phương pháp tỉa, mỗi hốc một hạt. Trồng dặm được tiến hành sau khi gieo 5 - 6 ngày. Sau 10 ngày gieo, phun thuốc phòng ngừa bệnh héo chết cây con.

Sau đó, quan sát thường xuyên và ghi nhận 
tình hình sâu bệnh hại để có biện pháp xử lý kịp thời.

\subsection{Các chỉ tiêu theo dõi}

Độ $\mathrm{pH}$ và hàm lượng $\mathrm{Cd}$ trong đất trước và sau thí nghiệm.

Hàm lượng $\mathrm{Cd}$ tích lũy trong thân và hạt cây đậu phộng sau thí nghiệm.

Chiều cao và số chồi được theo dõi trên 10 cây cố định trên mỗi lần lặp lại ở mỗi nghiệm thức ở các thời điểm 20, 45, 65 ngày sau khi gieo (NSG) và lúc thu hoạch.

Năng suất thu hoạch ở mỗi nghiệm thức sau thí nghiệm.

\subsection{Phân tích số liệu}

Số liệu sẽ được phân tích phương sai và kiểm định DUNCAN ở mức ý nghĩa $5 \%$ để so sánh sự khác biệt giữa các nghiệm thức bằng chương trình SPSS Statistics 22. Sử dụng phần mềm Excel 2010 để xử lý số liệu trung bình và vẽ các đồ thị.

\section{Kết Quả và Thảo Luận}

\section{1. Ảnh hưởng của vôi và mụn dừa đến $\sinh$ trưởng và các yếu tố cấu thành năng suất cây đậu phộng}

\subsection{1. Ảnh hưởng của vôi và mụn dừa lên chiều cao và số chồi qua các giai đoạn sinh trưởng và phát triển của cây đậu phộng}

Ảnh hưởng của vôi và mụn dừa đến chiều cao cây đậu phộng được trình bày ở Bảng 2. Chiều cao của cây đậu phộng giữa các nghiệm thức ở giai đoạn 20 NSG không có sự khác biệt thống kê nhưng nghiệm thức $\mathrm{BMD}+\mathrm{V}$ cây đậu phộng có chiều cao lớn nhất là $12,4 \mathrm{~cm}$ cao hơn 3 nghiệm thức còn lại. Kế đến nghiệm thức $B M D$ và $B V$ có chiều cao là không khác biệt nhau, nhưng cao hơn nghiệm thức ĐC có chiều cao là $11,8 \mathrm{~cm}$. Nhìn chung ở giai đoạn $20 \mathrm{NSG}$ các hình thức $\mathrm{BV}$ và BMD chưa có ảnh hưởng rõ rệt lên sự sinh trưởng của cây đậu phộng. Ở giai đoạn 45 NSG sự khác biệt về chiều cao ghi nhận được chủ yếu là do sự khác biệt bốn nghiệm thức thí nghiệm, nghiệm thức $\mathrm{BMD}+\mathrm{V}$ có chiều cao lớn nhất, khác biệt ý nghĩa $5 \%$ với nghiệm thức còn lại. Chiều cao các nghiệm thức còn lại được xếp theo thứ tự lần lượt là $\mathrm{DC}, \mathrm{BV}, \mathrm{BMD}$. Giai đoạn 65 NSG và thu hoach (100 NSG) có xu hướng tương tự nhau có sự khác biệt giữa các nghiệm thức do ảnh hưởng tương tác của các thí nghiệm là cách bón phân ở mức ý nghĩa 5\%. Nghiệm thức BMD+V khi thu hoạch có chiều cao trung bình cao nhất là 73,9 $\mathrm{cm}, \mathrm{BMD}$ có chiều cao tiếp theo là $72,7 \mathrm{~cm}, 71,8$ $\mathrm{cm}$ là chiều cao của nghiệm thức $\mathrm{BV}$ và thấp nhất là ĐC là $59,1 \mathrm{~cm}$.

Chiều cao của cây đậu phộng giữa các nghiệm thức ở giai đoạn 20 NSG không có sự khác biệt thống kê nhưng nghiệm thức $\mathrm{BMD}+\mathrm{V}$ cây đậu phộng có chiều cao lớn nhất là $12,4 \mathrm{~cm}$ cao hơn 3 nghiệm thức còn lại. Kế đến nghiệm thức $B M D$ và $\mathrm{BV}$ có chiều cao là không khác biệt nhau, nhưng cao hơn nghiệm thức ĐC có chiều cao là $11,8 \mathrm{~cm}$. Nhìn chung ở giai đoạn 20 NSG các hình thức $B V$ và $B M D$ chưa có ảnh hưởng rõ rệt lên sự sinh trưởng của cây đậu phộng. Ở giai đoạn 45 NSG sự khác biệt về chiều cao ghi nhận được chủ yếu là do sự khác biệt bốn nghiệm thức thí nghiệm, nghiệm thức $\mathrm{BMD}+\mathrm{V}$ có chiều cao lớn nhất, khác biệt ý nghĩa $5 \%$ với nghiệm thức còn lại. Chiều cao các nghiệm thức còn lại được xếp theo thứ tự lần lượt là $\mathrm{DC}, \mathrm{BV}, \mathrm{BMD}$. Giai đoạn $65 \mathrm{NSG}$ và thu hoach (100 NSG) có xu hướng tương tự nhau có sự khác biệt giữa các nghiệm thức do ảnh hưởng tương tác của các thí nghiệm là cách bón phân ở mức ý nghĩa 5\%. Nghiệm thức $\mathrm{BMD}+\mathrm{V}$ khi thu hoạch có chiều cao trung bình cao nhất là $73,9 \mathrm{~cm}, \mathrm{BMD}$ có chiều cao tiếp theo là 72,7 $\mathrm{cm}, 71,8 \mathrm{~cm}$ là chiều cao của nghiệm thức $\mathrm{BV}$ và thấp nhất là ĐC là $59,1 \mathrm{~cm}$.

3.1.2. Ảnh hưởng của bón vôi và mụn dừa đến thành phần năng suất của cây trồng

Kết quả Bảng 3 cho thấy thành phần năng suất của cây đậu phộng gần tương tự với chỉ tiêu về số chồi, đều có nghiệm thức $\mathrm{BMD}+\mathrm{V}$ đạt cao nhất và khác biệt ý nghĩa ở mức $5 \%$ so với nghiệm thức còn lại, kế đến là nghiệm thức $\mathrm{BV}$ và $\mathrm{BMD}$, thấp nhất là ĐC. Sinh khối trung bình 10 cây ở nghiệm thức $\mathrm{BMD}+\mathrm{V}$ đối với thân là $7,6 \mathrm{~kg} / 10$ cây và trái là $802 \mathrm{~g} / 10$ cây và nghiệm thức ĐC có sinh khối trung bình 10 cây là thấp nhất (thân $5,85 \mathrm{~kg} / 10$ cây, trái $531 \mathrm{~g} / 10$ cây). Kết quả Bảng 3 cũng cho thấy trọng lượng 100 hạt trên cây đậu ở các nghiệm thức có khác biệt ý nghĩa thống kê ở mức ý nghĩa $5 \%$ và được xếp theo mức độ từ cao xuống thấp BMD $+\mathrm{V}>\mathrm{BMD}>\mathrm{BV}>\mathrm{DC}$. Số trái/cây dao động từ 30,1 - 42,8, giữa các nghiệm thức khác biệt $5 \%$ về mặt thống kê. Tỉ lệ hạt chắc, 
Bảng 2. Ảnh hưởng của vôi và mụn dừa đến chiều cao cây đậu phộng $(\mathrm{cm})$

\begin{tabular}{lcccc}
\hline Nghiệm thức & 20 NSG & 45NSG & $65 \mathrm{NSG}$ & Thu hoạch \\
\hline Không bón vôi, mụn dừa (ĐC) & $11,8^{\mathrm{c}}$ & $29,1^{\mathrm{d}}$ & $40,9^{\mathrm{c}}$ & $59,1^{\mathrm{d}}$ \\
Bón vôi (BV) & $12,0^{\mathrm{b}}$ & $29,8^{\mathrm{c}}$ & $40,8^{\mathrm{c}}$ & $71,8^{\mathrm{c}}$ \\
Bón mụn dừa (BMD) & $12,0^{\mathrm{b}}$ & $31,1^{\mathrm{b}}$ & $42,5^{\mathrm{b}}$ & $72,7^{\mathrm{b}}$ \\
Bón mụn dừa + vôi (BMD+V) & $12,4^{\mathrm{a}}$ & $33,2^{\mathrm{a}}$ & $43,9^{\mathrm{a}}$ & $73,9^{\mathrm{a}}$ \\
\hline $\mathrm{CV}(\%)$ & 2,10 & 5,90 & 3,50 & 10,0 \\
\hline $\mathrm{F}$ & $2.797^{\mathrm{ns}}$ & $9.131^{*}$ & $13.802^{*}$ & $26.114^{*}$ \\
\hline a-d Trong cùng một cột giá trị trung bình, các số có cùng ký tự đi kèm thể hiện sự khác biệt không \\
có ý nghĩa thống kê; ns: không khăc biệt; *: khác biệt có ý nghĩa ở mức $\alpha=0.05$.
\end{tabular}

số chồi cũng có sự khác biệt giữa các nghiệm thức ở mức 5\%. Cây đậu phộng ra hoa và thư đài hình thành nách lá, thư đài sẽ mọc xuống đất phát triển thành trái, do vậy nếu cây có nhiều chồi thì sẽ cho ra nhiều hoa và trái (Nguyen \& ctv. 2011). Từ đó việc $\mathrm{BMD}+\mathrm{V}$ giúp cây đậu phộng đẻ nhiều chồi, tăng khả năng ra hoa nhằm giúp tăng năng suất thu hoạch trái cho nông dân.

\section{2. Ảnh hưởng của vôi và mụn dừa đến $\mathrm{pH}$ và hàm lượng $\mathrm{Cd}$ trong đất}

\subsection{1. pH trong đất trước và sau thí nghiệm}

pH là yếu tố liên quan đến sự hòa tan và hấp phụ của các hạt keo trong đất. Tính hoà tan và tính linh động của kim loại trong đất phụ thuộc nhiều vào các tiến trình hoá học và các đặc tính khác nhau của đất (De Matos \& ctv., 2001). Kêt quả phân tích đất trước thí nghiệm (Bảng 4) cho thấy không có sự khác biệt thống kê về $\mathrm{pH}$ đất giữa bốn nghiệm thức. Trước thí nghiệm $\mathrm{pH}$ cao nhất là 6,7 ở nghiệm thức $\mathrm{BV}$ và thấp nhất là 6,4 là nghiệm thức $\mathrm{BMD}, \mathrm{pH}$ dất $\mathrm{DC}$ và $\mathrm{BMD}+\mathrm{V}$ dừa lần lượt là 6,5 và 6,6 . Tuy nhiên, kết quả đất sau thí nghiệm (Bảng 4) cho thấy nghiệm thức không bón vôi và mụn dừa $\mathrm{pH}$ có xu hướng giảm thấp. $\mathrm{pH}$ đất biến động từ 6,5 trước thí nghiệm xuống 6,4 sau thí nghiệm. Nhìn chung, các nghiệm thức $\mathrm{BV}$ và $\mathrm{MD}$ sau thí nghiệm đều tăng và khác biệt thống kê ý nghĩa $5 \%$, ngoại trừ nghiệm thức ĐC giảm nhẹ.

Kết quả phân tích thống kê cho thấy pH trong đất có sự gia tăng ở các nghiệm thức sau thí nghiệm so với $\mathrm{pH}$ đất trước thí nghiệm. Trong đó, $\mathrm{pH}=7,6$ của nghiệm thức $\mathrm{BMD}+\mathrm{V}$ là cao nhất luôn cao hơn và khác biệt ý nghĩa thống kê $5 \%$ với $\mathrm{pH}$ trong đất ở các nghiệm thức khác có trung bình từ $\mathrm{pH}=7,4$ đến 6,4 .

\subsubsection{Cadimi trong đất trước và sau thí nghiệm}

Ô nhiễm Cd của đất từ hoạt động nông nghiệp thường do việc sử dụng các loại phân phốt phát. Tuy hàm lượng $\mathrm{Cd}$ trong đất nông nghiệp không cao so với các tiêu chuẩn $(1,5 \mathrm{mg} / \mathrm{kg})$, nhưng lại là nỗi lo do nguy cơ gây nhiễm Cd lên các chuỗi thức ăn gây ảnh hưởng đến sức khỏe con người (Mclaughlin \& ctv., 1998).

Kết quả phân tích đất trước khi tiến hành thí nghiệm (Bảng 5) cho thấy đất thu tại xã Quốc Thái có hàm lượng $\mathrm{Cd}$ tương đối cao nhưng không khác biệt thống kê. Ở nghiệm thức $\mathrm{BV}$ và $\mathrm{DC}$ lần lượt là $240 \mu \mathrm{g} / \mathrm{kg}, 239 \mu \mathrm{g} / \mathrm{kg}$ cao hơn so với 2 loại đất còn lại $\mathrm{BMD}$ hàm lượng $\mathrm{Cd}$ trong đất là 235 $\mu \mathrm{g} / \mathrm{kg}$ và đất $\mathrm{BMD}+\mathrm{V}$ có $\mathrm{Cd}$ trong đất là 237 $\mu \mathrm{g} / \mathrm{kg}$.

Sau thí nghiệm, ở các nghiệm thức cho thấy hàm lượng $\mathrm{Cd}$ trong đất giảm đáng kể so với trước thí nghiệm. Điều này được giải thích là do $\mathrm{Cd}$ trong đất đã được cây trồng hấp thu và tích lũy trong các bộ phận của cây và hạt. Hàm lượng $\mathrm{Cd}$ trong đất đạt cao nhất ở các nghiệm thức trồng đậu phộng khi được BV hoặc BMD+V là 230 $\mu \mathrm{g} / \mathrm{kg}$. Hàm lượng $\mathrm{Cd}$ đạt thấp nhất ở nghiệm thức đối chứng là $190 \mu \mathrm{g} / \mathrm{kg}$ và khác biệt với các nghiệm thức còn lại ở mức ý nghĩa $5 \%$. So sánh các nghiệm thức thì hàm lượng $\mathrm{Cd}$ trong đất $\mathrm{BMD}+\mathrm{V}$ đạt cao nhất là $230 \mu \mathrm{g} / \mathrm{kg}$ và khác biệt với hàm lượng $\mathrm{Cd}$ trong đất ở nghiệm thức ĐC cho thấy tác dụng của $\mathrm{CaO}$ đã làm cho lượng Cd được giữ lại trong đất nhiều hơn do bị kết tủa ở dạng $\mathrm{CdCO}_{3}$ so với các nghiệm thức không bón vôi và phù hợp với nghiên cứu của Shukla \& ctv. (2006) cho rằng mụn dừa hấp phụ các ion kim loại nặng và giữ chúng trên bề mặt vật liệu. Nên nghiệm thức $\mathrm{BMD}$ cũng làm cho lượng $\mathrm{Cd}$ được giữ lại trong đất là $210 \mu \mathrm{g} / \mathrm{kg}$ cao hơn nghiệm thức không bón vôi, mụn dừa. 


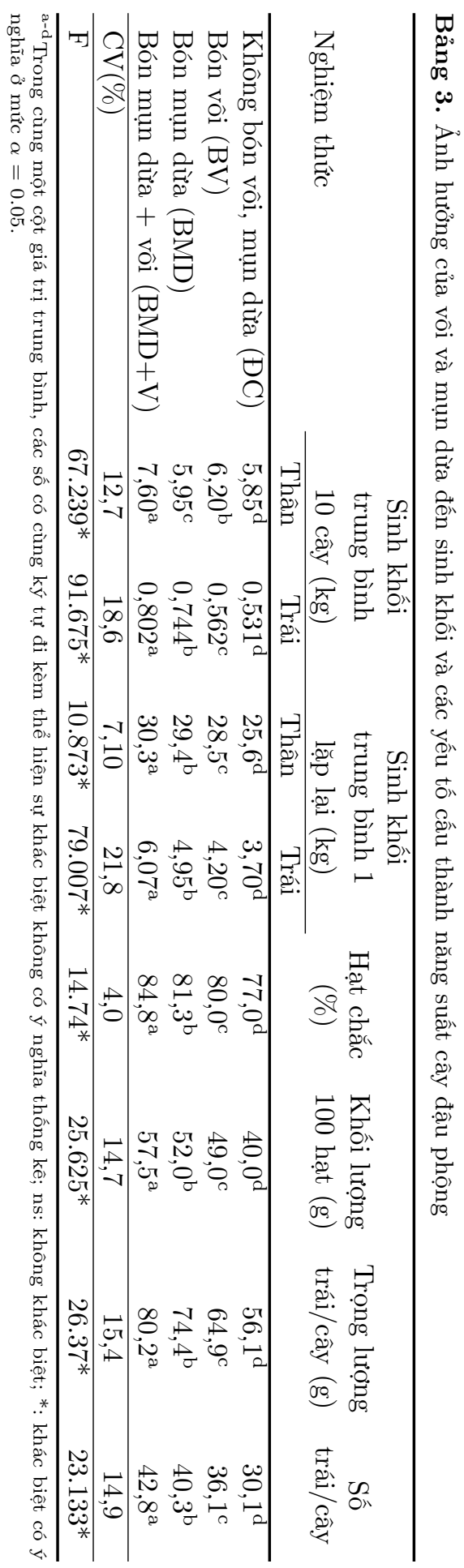

\section{3. Ảnh hưởng của biện pháp bón vôi và mụn dừa lên sự hấp thu Cadimi trên cây đậu phộng tại xã Quốc Thái, huyện An Phú - An Giang}

Kết quả phân tích Bảng 6 cho thấy hàm lượng $\mathrm{Cd}$ trong hạt và hàm lượng $\mathrm{Cd}$ trong thân có sự khác biệt giữa bốn nghiệm thức được xếp theo thứ tự giảm dần theo từng nghiệm thức $\mathrm{DC}>$ $\mathrm{BMD}>\mathrm{BV}>\mathrm{BMD}+\mathrm{V}$ với khác biệt ý nghĩa thống kê ở mức ý nghĩa $5 \%$. Cadimi tích lũy trong thân đậu phộng dao động từ $81,0 \mu \mathrm{g} / \mathrm{kg}$ - 100 $\mu \mathrm{g} / \mathrm{kg}$ và trong hạt dao động từ $27,0 \mu \mathrm{g} / \mathrm{kg}$ dến $35,0 \mu \mathrm{g} / \mathrm{kg}$. Qua đó cho thấy đậu phộng đều có khả năng tích lũy $\mathrm{Cd}$ trong thân nhiều hơn trong hạt gấp 3 lần.

Kết quả phân tích Bảng 6 cho thấy hàm lượng Cd trong thân và hạt có sự khác biệt rất lớn giữa 4 nghiệm thức thí nghiệm. Trong đó, hàm lượng Cd trong hạt và trong thân được ghi nhận đạt cao nhất lần lượt là $35,0 \mu \mathrm{g} / \mathrm{kg}, 100 \mu \mathrm{g} / \mathrm{kg}$ ở nghiệm thức ĐC, kế đến là $33,0 \mu \mathrm{g} / \mathrm{kg}, 90 \mu \mathrm{g} / \mathrm{kg}$ ở nghiệm thức $\mathrm{BMD}$, thấp nhất ở nghiệm thức $\mathrm{BMD}+\mathrm{V}$ là $27,0 \mu \mathrm{g} / \mathrm{kg}, 81 \mu \mathrm{g} / \mathrm{kg}$ và khác biệt ý nghĩa thống kê ở mức ý nghĩa $5 \%$ so với hàm lượng $\mathrm{Cd}$ tích lũy trong thân và hạt ở nghiệm thức BV lần lượt là $84,0 \mu \mathrm{g} / \mathrm{kg}$ và $29,0 \mu \mathrm{g} / \mathrm{kg}$. Kết quả này phù hợp với nghiên cứu của Sarma \& ctv. (2006) cho thấy nồng độ $\mathrm{Cd}$ trong thực vật giảm theo thứ tự là: gốc, lá, trái cây, hạt giống. Một số nghiên cứu báo cáo rằng ngay cả ở nồng độ tương đối thấp nó cũng có thể làm thay đổi sự trao đổi chất thực vật (Van Asshe \& Clijsters, 1990). Theo nghiên cứu của Hasan \& ctv. (2007) cho thấy sự gia tăng hàm lượng $\mathrm{Cd}$ làm giảm khối lượng tươi của cây trồng.

Kết quả này phù hợp với nghiên cứu của Tan \& ctv. (2011) cho rằng đối với đất nhiễm $\mathrm{Cd}$, bón vôi sẽ làm giảm sự hấp thu kim loại này vào cây trồng trung bình từ $40 \%-50 \%$ và tối đa là $70 \%$. Sự giảm hấp thu Cd là do sự bất động của chúng trong đất. Bên cạnh đó thì hàm lượng $\mathrm{Cd}$ trong hạt cũng có sự khác biệt rất lớn giữa các nghiệm thức thí nghiệm. Giữa 4 nghiệm thức thí nghiệm thì nghiệm thức ĐC và nghiệm thức $\mathrm{BMD}$ có sự tích lũy $\mathrm{Cd}$ trong hạt cao hơn và khác biệt so với nghiệm thức $\mathrm{BV}$ và nghiệm thức $\mathrm{BMD}+\mathrm{V}$ ở mức ý nghĩa $5 \%$. Qua đó cho thấy nghiệm thức $\mathrm{BMD}+\mathrm{V}$ có khả năng giữ lại hàm lượng $\mathrm{Cd}$ trong đất tốt nhất nên hàm lượng $\mathrm{Cd}$ trong hạt là thấp nhất $27,0 \mu \mathrm{g} / \mathrm{kg}$, tiếp đến nghiệm thức $\mathrm{BV}$ cũng có thể giảm sự hấp thu $\mathrm{Cd}$ vào hạt $29,0 \mu \mathrm{g} / \mathrm{kg}$. Điều này được giải thích là do ở các nghiệm thức 
Bảng 4. Ảnh hưởng của vôi và mụn dừa đến $\mathrm{pH}$ trong đất trước và sau thí nghiệm

\begin{tabular}{lcc}
\hline Nghiệm thức & Trước thí nghiệm & Sau thí nghiệm \\
\hline Bón vôi $(\mathrm{BV})$ & 6,7 & $7,4^{\mathrm{ab}}$ \\
Bón mụn dừa $(\mathrm{BMD})$ & 6,4 & $6,8^{\mathrm{b}}$ \\
Bón mụn dừa + vôi $(\mathrm{BMD}+\mathrm{V})$ & 6,6 & $7,6^{\mathrm{a}}$ \\
\hline CV $(\%)$ & 1,97 & 7,8 \\
\hline F & $5.4^{\mathrm{ns}}$ & $66.858^{*}$ \\
\hline
\end{tabular}

a-b Trong cùng một cột giá trị trung bình, các số có cùng ký tự đi kèm thể hiện sự khác biệt không có ý nghĩa thống kê; ns: không khác biệt; *: khác biệt có ý nghĩa ở mức $\alpha=0.05$.

Bảng 5. Ảnh hưởng của vôi và mụn dừa đến hàm lượng Cadimi $(\mu \mathrm{g} / \mathrm{kg})$ trong đất trước và sau thí nghiệm

\begin{tabular}{lcc}
\hline Nghiệm thức & Trước thí nghiệm & Sau thí nghiệm \\
\hline Không bón vôi, mụn dừa (ĐC) & 239 & $190^{\mathrm{c}}$ \\
Bón vôi $(\mathrm{BV})$ & 240 & $230^{\mathrm{a}}$ \\
Bón mụn dừa (BMD) & 235 & $210^{\mathrm{b}}$ \\
Bón mụn dừa + vôi (BMDV) & 237 & $230^{\mathrm{a}}$ \\
\hline $\mathrm{CV}(\%)$ & 0,9 & 8,9 \\
\hline $\mathrm{F}$ & $0.142^{\mathrm{n}}$ & $16.762^{*}$ \\
\hline a-c Trong cùng một cột giá trị trung bình, các số có cùng ký tự đi kèm thể hiện sự khác biệt không có ý nghĩa \\
thống kê; ns: không khác biệt; *: khác biệt có ý nghĩa ở mức $\alpha=0.05$.
\end{tabular}

Bảng 6. Ảnh hưởng của vôi và mụn dừa đến hàm lượng Cadimi trong thân và hạt đậu phộng

\begin{tabular}{lcc}
\hline \multirow{2}{*}{ Nghiệm thức } & \multicolumn{2}{c}{ Hàm lượng Cd trong bộ phận $(\mu \mathrm{g} / \mathrm{kg})$} \\
\cline { 2 - 3 } & \multicolumn{1}{c}{ Thận } \\
\hline Không bón vôi, mụn dừa $(\mathrm{DC})$ & $100^{\mathrm{a}}$ & $35,0^{\mathrm{a}}$ \\
Bón vôi (BV) & $84,0^{\mathrm{c}}$ & $29,0^{\mathrm{c}}$ \\
Bón mụn dừa (BMD) & $90,0^{\mathrm{b}}$ & $33,0^{\mathrm{b}}$ \\
Bón mụn dừa + vôi (BMDV) & $81,0^{\mathrm{d}}$ & $27,0^{\mathrm{d}}$ \\
\hline CV (\%) & 9,4 & 11,8 \\
\hline a-d Trong cùng một cột giá trị trung bình, các số có cùng ký tự đi kèm thể hiện sự khác biệt không có ý nghĩa
\end{tabular}
thống kề; ns: không khác biệt; *: khác biệt có ý nghĩa ở mức $\alpha=0.05$.

có BV, BMD đã giúp giữ lại Cd trong đất nhiều hơn ở nghiệm thức ĐC nên đã làm giảm sự hấp thu và tích lũy $\mathrm{Cd}$ trong thân và hạt của cây đậu phộng. Từ đó cho thấy việc $\mathrm{BMD}+\mathrm{V}$ (5 tấn/ha) có hiệu quả cố định $\mathrm{Cd}$ trong đất giảm sự hấp thu $\mathrm{Cd}$ vào nông sản góp phần bảo vệ sức khỏe người tiêu dùng.

\section{Kết Luận và Kiến Nghị}

\subsection{Kết luận}

Việc bón vôi và mụn dừa đã làm tăng độ $\mathrm{pH}$ giúp cố định $\mathrm{Cd}$ trong đất. Tất cả các mẫu đất trồng đậu phộng trong đê đều bị nhiễm $\mathrm{Cd}$ từ 235 $\mu \mathrm{g} / \mathrm{kg}$ đến $240 \mu \mathrm{g} / \mathrm{kg}$. Hàm lượng $\mathrm{Cd}$ trong hạt và trong thân của cây đậu phộng trồng không bón vôi và mụn dừa luôn cao hơn các nghiệm thức có bón vôi và mụn dừa.

Đối nghiệm thức bón vôi kết hợp với mụn dừa cho thây hiệu quả cao nhất, mức độ giảm thiểu sự hấp thu $\mathrm{Cd}$ từ môi trường đất vào trong thân và hạt là thấp nhất, kế đến là nghiệm thức bón vôi, bón mụn dừa vẫn cho kết quả có hàm lượng Cd trong thân và hạt thấp hơn đối chứng lần lượt từ $17 \%$ đến $34 \%$ và $16 \%$ đến $19 \%$.

Kết quả các chỉ tiêu nông học như chiều cao, số chồi và các thành phần về năng suất cho thấy trồng đậu phộng có bón vôi kết hợp mụn dừa cho kết quả tốt nhất, tiếp theo bón mụn dừa, bón vôi và thấp nhất là trồng không bón thêm vôi và mụn dừa. Nghiên cứu cho thấy bón vôi và mụn dừa ở mức độ 5 tấn/ha mỗi loại làm giảm khả năng hấp thu $\mathrm{Cd}$ vào cây trồng. 


\subsection{Kiến nghị}

Cần theo dõi thường xuyên về hàm lượng $\mathrm{Cd}$ trong đất để có cảnh báo phù hợp cho người dân và cần có những nghiên cứu qua nhiều mùa vụ để thấy được tác ảnh hưởng của vôi và mụn dừa lên sự biến đổi lý hóa tính đất và quần thể vi sinh vật trong đất, cũng như sinh trưởng và năng suất cây trồng. Xem xét sự lưu tồn của vôi và mụn dừa khi bị phân hủy thành chất hữu cơ đối với khả năng làm giảm hấp thu hàm lượng $\mathrm{Cd}$ vào cây trồng và tăng độ phì khi canh tác trên đất An Phú.

\section{Tài Liệu Tham Khảo (References)}

Chen, H. M., Zheng, C. R., Tu, C., \& Shen, Z. G. (2000). Chemical methods and phytoremediation of soil contaminated with heavy metals. Chemosphere 41(1-2), 229-234.

De Matos, A. T., Fontes, M. P. F., da Costa, L. M., \& Martinez, M. A. (2001). Mobility of heavy metals as related to soil chemical and mineralogical characteristics of Brazilian soils. Environmental Pollution 111(3), 429-435.

Hasan, S. A., Hayat, S., Ali B., \& Ahmad A. (2007). 28homobrassinolide protectschickpea (Cicer arietinum) from cadmium toxicity by stimulatingantioxidant. Environmental Pollution 151(1), 60-66.

Mclaughlin M. J., Hamon R. E., Maier N. A., Correll R. L., Smart M. K., Grant C. D. (1998). In-situ immobilisation techniques to remediate cadmium-contaminated agricultural soils. In: Proceedings of the $6^{\text {th }}$ International FZK/TNO Conference on Contaminated Soil (453-460). Edinburgh, UK.

MOH (Ministry of Health). (2011). Circular No. QCVN 8-2:2011/BYT dated on January 13, 2011. National technical regulation on the limits of heavy metals contamination in food. Ha Noi, Vietnam: MOH Office.

MONRE (Ministry of Natural Resources \& Environment). (2015). Circular No. QCVN 03MT:2015/BTNMT dated on December 21, 2015. National technical regulation on the allowable limits of heavy metals in the soils. Ha Noi, Vietnam: MONRE Office.
Nguyen, C. V., \& Ngo, H. N. (2015). Research on mitigating of rice, maize and mung beans uptake of cadmium in An Phu district, An Giang province. Journal of Agriculture and Rural Development 12, 72-77.

Nguyen, C. V., \& Ngo, H. N. (2012). The demand of phosphate and the correlation with phosphate-cadimi in corn, rice and mungbean cultivated on slob at An Phu. Journal of Agriculture and Rural Development 1, 101-106.

Nguyen, O. H. (2003). Status of using phosphate fertilizer in agriculture and estimation of $C d$ contamination in the environment in MeKong Delta (Unpublished master's thesis). The College of Agriculture, Can Tho University, Can Tho, Vietnam.

Nguyen, V. B., Tran, B. T. K., Nguyen, T. T. X., \& Le, T. V. (2011). Short-term industrial plants-lecture notes (106-179). Can Tho, Vietnam: Can Tho University.

Nogawa, K. (1984). Cadmium in changing metal cycles and human health. In Nriagu, J. O. (Ed.). Changing metal cycles and human health (275-284). Berlin, Germany: Springer.

Sarma, M., Gautam, K. H., \& Handique, A. K. (2006). Toxic heavy metal stress in paddy: Metal accumulation profile and development of a novel stress protein in seed. Indian Journal of Plant Physiology 11(3), 227233.

Shukla, S. R., Pai, R. S., \& Shendarkar, A. D. (2006). Adsorption of $\mathrm{Ni}(\mathrm{II}), \mathrm{Zn}(\mathrm{II})$ and $\mathrm{Fe}(\mathrm{II})$ on modified coir fibres. Separation and Purification Technology 47(3), 141-147.

Tan, W. N., Li, Z. A., Qiu, J., Zou, B., Li, N. Y., Zhuang, P., \& Wang, G. (2011). Lime and phosphate could reduce cadmium uptake by five vegetables commonly grown in South China. Pedosphere 21(2), 223-229.

Van Asshe, F., \& Clijsters, H. (1990). Effects of metals on enzyme activity in plant. Plant, Cell and Environment 13, 195-206. 